This is an Accepted Manuscript of an article published by Oxford University Press in European Review of Economic History, 14 Oct 2018, available online in https://doiorg.sire.ub.edu/10.1093/ereh/hey027

\title{
Measuring Extractive Institutions: \\ Colonial Trade and Price Gaps in French Africa
}

\author{
Federico Tadei*
}

This is an Accepted Manuscript of an article published by Oxford Academic in the European Review of Economic History, 31 Oct 2018, available online at https://doiorg.sire.ub.edu/10.1093/ereh/hey027

Colonial extractive institutions are often blamed for current African underdevelopment. Yet, since colonial extraction is hard to quantify, the magnitude of this phenomenon remains unclear. In this paper, I use new archival data to estimate colonial extraction through trade, measured as the gap between prices that the monopsonistic French trading companies paid to African producers and prices that should have been paid in a counterfactual competitive market. The results show that African prices were only a small fraction of competitive prices, implying an annual loss of almost 2\% of GDP during colonial rule.

JEL Classification: N17; 043

Keywords: Africa, Development, Extractive Institutions, Colonization, Trade, Price Gaps 
* Department of Economic History, Institutions and Policy, and World Economy, and BEAT Barcelona Economics Analysis Team, University of Barcelona, Avenida Diagonal 690, 08012 Barcelona, Spain. Email: federico.tadei@ub.edu. 


\section{Introduction}

Many leading hypotheses about current African underdevelopment emphasize the role of colonialism. While early literature has explored how colonial rule relegated Africa to the role of exporter of primary commodities (Rodney 1972), more recent works have instead focused on the long-term consequences of colonial extractive institutions (Acemoglu, Johnson, and Robinson 2001 and 2002; Englebert 2000; Herbst 2000; Nunn 2007). ${ }^{1}$ Yet, to explain how colonial institutions have affected current development, the extent of extraction during the colonial period needs to be further explored. Many of the institutions established by the colonizers were, in fact, maintained in the post-independence period. Moreover, the extent to which they were extractive in the colonial period affects how extractive they are after independence (Acemoglu, Johnson, and Robinson 2001; Bates 1981).

However, since colonial extraction is hard to quantify and its exact mechanisms are unclear, we still do not know precisely how successful the colonizers were in extracting wealth from Africans. While historians have collected information about colonial institutions, they have not systematically quantified the level of extraction. In this same vein, economists have often overlooked the temporal variation in colonial extraction, increasing the risk of "compression of history" and making it difficult to understand how extractive institutions vary over time (Austin 2008). ${ }^{2}$ One of the main reasons for this gap in the literature is that extractive institutions were used in all colonies, creating challenges in finding appropriate counterfactuals.

In this paper, I tackle this issue by exploiting the peculiar structure of labor and trade policies implemented by the French colonizers. In French Africa, because of the low population density and the high cost of labor relative to land, the colonizers faced powerful incentives to implement extractive institutions such as labor coercion and trade monopsonies. Thanks to these arrangements, colonial trading companies were able to obtain agricultural commodities from African producers at very low prices and resell them in Europe for large profits. ${ }^{3}$ This

specific feature of French trade allows us to estimate the magnitude of colonial extraction by looking at the difference between the prices that the African producers received and the prices that they should have received had the colonizer not implemented trade monopsonies and coercive labor institutions. In other words, we can use producer prices in a competitive market - calculated as the difference between world market prices and trading costs - as a counterfactual to measure the extent of colonial extraction via trade. 
To implement this idea, I first constructed a new yearly dataset of prices at the African ports and in France for the main commodities exported from each French colony in SubSaharan Africa between 1898 and 1959. I collected these data from a variety of colonial publications, including statistical reports of the Ministry of the Colonies, customs statistics, and Bulletins Economiques of the different colonies. To estimate prices at the producer level, I relied on the fact that colonial publications reported prices at the African port as the sum of producer prices and trade costs between the producer and the port. Thus, by measuring these inland trade costs, I was able to estimate producer prices. To evaluate what they should have been in a competitive market, I first constructed estimates of trading costs including Atlantic shipping, insurance, inland transportation, port charges, and export taxes, by using a variety of historical sources. To the best of my knowledge, this is the first attempt to provide systematic estimates of trade costs in French Africa. I then computed competitive producer prices by subtracting these costs from the prices at the French port. Finally, by comparing actual and competitive producer prices, I estimated the level of colonial extraction in export trade. The results show that actual producer prices were much lower than what they should have been in a competitive market: extraction rates varied by colony, commodity, and over time, and ranged from $20 \%$ to over $70 \%$.

The procedure described above relies on correctly taking into account all trading costs. Yet, even if we correctly estimate observable trade costs, one could still worry that the measured difference between actual and competitive producer prices might be due to other unobservable factors. These could include costs related to quality differences, market frictions, mechanisms of insurance for producers, compensation for risk and uncertainty in colonial trade, and productivity differences. To address these issues, I regressed actual prices on competitive prices, while taking into account unobservable costs by using colony, commodity, and year fixed effects. This was done to examine the extent to which an increase in the competitive price was reflected in an increase in the producer price or in an increase in the profit of the colonizer. As an additional approach to control for unobservable factors, I also used instrumental variables by instrumenting the competitive producer price with world market price. The key identifying assumption is that, since French trade from Africa accounted for only a very small part of world trade, world prices are uncorrelated with unobservable trade costs within the French colonies. The results from both regression approaches show that, even after taking into account unobservable factors, the difference between actual and competitive producer prices remains very large and significant. 
Together, the evidence suggests that prices to African producers were much lower than competitive prices and that this difference cannot be explained by observable or unobservable trade costs. On average, prices to African producers were about half of what they would have been in the absence of monopsonies and coercive institutions. ${ }^{4}$ To interpret these estimates, it is important to recognize the counterfactual examined. Instead of comparing African prices to what they would have been without colonization, I compared to them to what they would have been had colonizers implemented non-extractive institutions. The results of the present paper do not dismiss the fact that Africans might have benefited from the increased access to international markets brought by colonization; rather, they underline that it was the colonizers (and not the colonies) who captured most of these benefits. The average annual loss due to monopsonistic colonial trade was equivalent to almost 2\% of GDP of West and Equatorial French Africa. It is hard to tell how the colonies would have developed without colonization extraction, but adding an additional $2 \%$ of annual GDP growth to the average $1 \%$ growth that these colonies experienced between 1900 and 1950 would mean more than doubling their per capita GDP at the eve of independence.

The rest of the paper is structured as follows. After a short summary of the relevant literature, section II presents the data. Section III discusses the methodology used to quantify colonial extraction. Section IV provides and interprets the price-gap estimates. Section V presents robustness checks and outlines the methodology to account for unobservable costs. Section VI offers concluding remarks and delineates directions of future research.

\section{Related Literature}

Looking at the difference between actual and competitive producer prices is one possible approach to measure colonial extraction. Alternative methodologies include considering the colony's balance of payment, comparing taxes and expenditures, or focusing on inequality.

By looking at the balance of payments, one could measure the net income that is transferred from the colony to the colonizing country in terms of import/exports and cash transfers. For example, Manning (1982) argued that in 1910 only 40\% of Dahomey government revenue was spent in the colony, while the rest was sent to Dakar and Paris. Roberts (1976) reported that between1930 and 1940, "Britain had kept for itself 2,400,000 pounds in taxes from the Copper-belt, while Northern Rhodesia received from Britain only 136,000 pounds in grants for development." 
The level of taxation can also be taken as a measure of extraction. For instance, to describe the extractive character of the colonial state, Acemoglu, Johnson, and Robinson (2001) cited Young (1994), who found that tax rates in Tunisia were four times larger than in France, and Peemans (1975), who demonstrated that African tax rates in Congo reached almost 60\%. In addition to the absolute level of taxation, it is also important to examine tax revenue expenditure. Frankema (2011) analyzed public finances in the British African colonies and constructed a measure of the extractive character of the State based on "the ratio of investments in 'human resources' - i.e. education and health care, versus the costs of establishing and maintaining 'colonial order' represented by the expenses on administration, domestic security and the military." Similarly, Huillery (2014) found that transfers from France accounted for only $2 \%$ of the revenue of French West Africa, and that most of it was spent for administration and the army. Furthermore, Milanovic, Lindert, and Williamson (2011) presented a different approach to measure extraction. In their work, they introduced the concept of inequality extraction ratio, defined as the ratio between the actual level of inequality in a society and the maximum feasible level of inequality, considering that everyone needs to have a subsistence income.

The aforementioned methodologies are based on a macro approach, focusing on the state's public finance or the overall level of inequality in the society. In contrast, the methodology used in this paper applies a more micro-oriented approach to estimate colonial extraction by focusing on a specific type of extractive institution: colonial trade policies. Nevertheless, all these methodologies are complementary. "Colonial extractive institutions" is a general term that includes many institutional arrangements ranging from trade policies, land and labor systems, and public finance. Thus, different approaches to measure colonial extraction shed light on different aspects of colonial rule and create a clearer understanding of extractive institutions during colonialism.

\section{Data}

Although both economists and historians agree on the importance of trade monopsonies and labor coercion during the French colonization of Africa, to date the extent of colonial extraction has been difficult to assess. In order to evaluate the magnitude of this phenomenon, it is imperative to identify a proper counterfactual. Since in a competitive market, without monopsonies and coercive labor markets, the prices to African producers should be equal to the difference between world market prices and trading costs, we can check for the presence of 
colonial extraction by analyzing whether prices to African producers in the French colonies were lower than these counterfactual competitive prices.

Ideally, we would like to observe prices at the producer level. However, the remaining records report only sparse information for some colonies/commodities and years. Therefore, it is not possible to use them in order to provide a general assessment of colonial extraction. Instead, what available records report is information on prices at the African and French ports and on trade costs, which I will describe in the following sub-sections.

\section{Prices in Africa}

I collected price data for four main agricultural commodities exported from French Africa between 1898 and 1959: peanuts (shelled and unshelled), palm kernels, ginned cotton, and cocoa beans. I included only commodities that were produced by African farmers. This is because, in the case of commodities produced under European plantations, the port price included also the profit of the concessionary company and it would not be a good measure of colonial extraction. Overall, the commodities in the dataset account for about two-thirds of the value of all exports from West and Equatorial French Africa during the entire colonial period.

Colonial customs statistics reported the total quantity and value of commodities exported from each colony every year. These statistics were registered at local customs offices and then aggregated at the colony level. The reported values were measured at the exit port and included the price paid to African producers together with processing, inland transport, warehousing and port costs, and in some cases customs duties. The sources used to gather these data include numerous yearly issues of different colonial publications, statistical reports of the Ministry of Colonies, Bulletins Economiques of the various colonies, and Annuaire Statistiques of West and Equatorial Africa. Online Appendix C provide more information on the specific sources.

\section{Prices in France}

I collected prices in France from various issues of the Statistiques Mensuelles du Commerce Extérieur de la France, a monthly publication by the Direction Générale des Douanes reporting the total values and quantities of the commodities imported from the French colonies every year. As a control, I also used different issues of the Annuaire Statistiques de France reporting similar information. 
Not all exports from French Africa went to France. Yet, given the importance of the French market, using import prices in France is a good benchmark against which to compare African export prices. By 1949, for instance, France was the destination of about $80 \%$ of the total exports originating from its African colonies (Duignan and Gann 1975). Moreover, as shown in section $\mathrm{V}$, extraction estimates are also robust to using world prices.

\section{Trading Costs}

In addition to price data, to estimate competitive prices we need to measure trade costs. They include shipping and insurance costs between the African and the French port, and inland transport, processing, warehousing, port costs, and export taxes between the producer and the African port. For the sake of space, I discuss the procedure I used to estimate each of these costs in Online Appendix C.

\section{How to Measure the Reduction of Producer Prices?}

\section{III.1 Methodology}

The price data described in section II are prices at the African port. Yet, we are interested in measuring colonial extraction faced by the producers. This gives rise to the following question: how can we use the available data on port prices to measure colonial extraction at the producer level? To solve this problem, we must first explore what an ideal measure of extraction looks like. If we had data on producer prices, we could measure extraction as the percentage gap between competitive and actual producer price

$$
E=\frac{(p-t-s)-p_{A}}{p-t-s}
$$

where $p-t-s$ is the competitive producer price (computed as difference between price in France $p$ and trading costs from the African port to France $t$ and from the producer to the African port $s$ ) and $p_{A}$ is the actual price paid to the producers. We can interpret this measure as how much the producers lost with respect to a situation of free trade.

How can we estimate equation (1) without information on producer prices $p_{A}$ ? The solution is provided by the specific way in which colonial customs offices reported values at the African 
port. These valuations included in fact the price paid to Africans $p_{A}$ producers together with inland trading costs $s$ (processing, inland transport, warehousing and port costs, customs duties). It is important to notice that this does not depend on the assumption of competition (or lack of extraction) in the internal markets, but just on how values were reported by customs offices. The valuations at the port were not the prices paid by the trading company to the intermediary at the port, but they were, by law, the sum of official producer prices and inland trading costs.

Several sources confirm this interpretation. Annuaire Statistiques, both from West and Equatorial Africa, report that the evaluations at customs offices were valeurs au point de sortie (exit point values) or valeurs mercuriales. The latter is defined as the sum of valeur d'achat (purchase value) from the producer, transport, and processing costs. These valuations were reported in such a way because customs offices were required to record the value of the good on which to levy duties (valeur imposable si la merchandise devait aquitter un droit ad valorem). In the later colonial period, in particular after WW2, these valuations also included customs duties and can be considered as Freight-On-Board (FOB) prices (Annuaire Statistique de l'AEF 1951-1955, Annuaire Statistique de l'AOF 1949-1951 and 1950-1954). Other sources confirm what was reported in the Annuaire Statistiques. For example, Dampierre (1960), describing cotton prices in Ubangi-Shari, mentioned how the prix de revient la cote (equivalent to the valuation at the exit port) was determined as the sum of the producer price fixed by the government, as a percentage of world market prices, and processing and inland transport costs. Similarly, Nabe (1999) reported that in Togo within the value at the exit port were included the producer price, taxes, and inland trading costs. In addition, direct data on cotton producer prices from Ubangi-Shari allows us to test these assumptions and confirm the validity of the proposed approach. The results of this analysis are reported in Online Appendix B.

Given the previous discussion, the price $p_{P}$ at the African port is equal to $p_{A}+s$ and we can thus estimate colonial extraction from known quantities as

$$
e=\frac{p-t-p_{P}}{p-t-s}
$$

\section{III.2 Historical Background}

How did colonial policies affect colonial extraction $e$ as defined in equation (2)? To see this, we need to go back to the history of French colonization in Africa. Most of the military conquest of 
French West and Equatorial Africa occurred between 1880 and 1900 and at the beginning of the 20th century more permanent institutions could be established (Coquery-Vidrovich 1969; Suret-Canale 1971). The French government organized the colonies in two federations: French West Africa (1895) - including Senegal, Mauritania, French Sudan (now Mali), Niger, Upper Volta (now Burkina Faso), Guinea, Ivory Coast, and Dahomey (now Benin)-and French Equatorial Africa (1908)-including Gabon, Congo, Ubangi-Shari (now Central African Republic), and Chad. After WW1, part of Togo and almost all of Cameroon were added to the French colonies in continental Sub-Saharan Africa. The extension of French possessions was reflected in the heterogeneity of their natural environment, including, from the coast towards the interior, tropical forests, savannas, and arid regions. The coastal forestry regions were suitable to produce bananas, coffee, cocoa, and rubber, while the drier interior areas were suitable for peanuts and cotton. In general, Western colonies were more prosperous than Equatorial colonies and, with the exception of the peanut-producing areas of Senegal, coastal regions were usually wealthier with respect to interior regions because of the higher value of their crops and lower transportation costs (Hopkins 1973).

Most of colonial economic activity revolved around trade. Exports were mainly based on production by African farmers, while European trading companies limited themselves to collect crops from Africans at trade posts and resell them at higher prices in Europe. The colonial government benefited from this trade by establishing customs duties and by taxing part of the companies' profit (Suret-Canale 1971). Nevertheless, given French Africa's low population densities and abundant cultivable land in the indigenous sector, African incentives to produce export crops were very limited. If the trading companies had been to pay free market prices, this would have greatly reduced their profit. For these reasons, they lobbied the colonial government to establish trade monopsonies and coercive labor market institutions, such as compulsory cultivations and various forms of forced labor. Some monopsonies were conceded de jure from the colonial government to specific companies, while others came into being de facto as a consequence of economic crises and protectionist policies (Coquery-Vidrovitch 1972; Manning 1998; Suret-Canale 1971; Thompson 1957). Formal monopsonies were established in the Equatorial colonies. Since the early XX century, the French government divided the territory of Equatorial Africa among concessionary companies with monopsony power. African laborers were forced to collect crops for the concessionaires who employed harsh coercive methods.

In West Africa, instead, de facto monopsonies became the norm. At the beginning of the 20th century, trade in the Senegal/Mali region was controlled by a group of eight Bordeaux 
trading firms, while Guinea was in the hands of business houses from Marseilles or Paris. Smaller traders were allowed a share of exports as long as they respected the prices fixed by the main trading firms. ${ }^{5}$ After $\mathrm{WW} 1$, the de facto monopsony of these companies grew stronger: economic crises eliminated competition from smaller companies, German business interests were canceled by the war, and protectionist measures were taken against British trade. Protectionist policies were not applied everywhere and did not completely eliminate nonFrench trade (especially in Guinea and Dahomey). Nevertheless, the number of the remaining trading firms became sufficiently small to allow agreement and ban entry into the African market (Suret-Canale 1971). As a result, at the beginning of WW2, about a dozen companies monopolized almost all of trade from French West Africa, and two French companies (Société Commerciale de l'Ouest Africain, Compagnie Française de l'Afrique Occidentale), and one BritishDutch company (Unilever) controlled between 50\% and 90\% of exports (Suret-Canale 1971, p. 167).

In addition to creating monopsony power for the trading companies, the colonizers attempted to reduce prices to Africans by interfering with labor markets and implementing coercive institutions. One option was to introduce compulsory cultivations. In this case, quotas were set of produce that Africans had to cultivate and sell for a fixed price to the colonizers. Moreover, in addition to compulsory cultivations, the colonizers also used indirect methods such as poll taxes. Introduced to raise the revenue of colonial governments, they also served the function of forcing Africans to produce cash crops in order to earn the money needed to fulfill their fiscal obligations. In Equatorial Africa, for example, poll taxes were introduced in 1902 as a way to facilitate rubber collection for the concessionary companies.

What was the potential impact of these monopsony and labor coercion policies on producer prices? The effect of monopsony is clear: a monopsonistic buyer is able to impose lower prices to the seller. The effect of labor coercion and production quotas is a reduction of the outside options of Africans. If outside options are limited, African farmers will be forced to accept lower prices.

\section{Results: Price Gap Estimates}

To evaluate systematically how effective colonial policies were in reducing producer prices, we can compute the price-gap extraction measure defined in equation (2). 


\section{IV.1 Main Result}

Table I presents the main estimates. The first six columns show means and standard deviations of French prices, competitive producer prices, and actual producer prices. Correlations between prices in France and at the producer level are also reported. The column labelled "extraction" reports mean estimates of $e$ as defined in equation (2) and equivalent to $E$ of equation (1) (i.e. extraction as a percentage of competitive counterfactual price) together with standard deviations. We can interpret these values as how much lower African prices were with respect to what they should have been if trade had been competitive.

The first row considers the full sample: extraction $e$, as defined in equation (3), is 0.32 . On average, prices at the producer were one third less of what they should have been in a competitive market, without monopsony and labor coercion. In the following rows, I checked whether this result is driven by specific periods, colonies, or commodities. In all samples, extraction rates are positive. All periods were subject to some extraction, ranging from $20 \%$ to $50 \%$. Looking at differences across commodities, we notice that extraction was particularly large for cotton (39\%), while it was lower for palm kernels, peanuts, and cocoa (27-33\%). Across colonies, average extraction ranged from $28 \%$ in Dahomey and Ivory Coast to $74 \%$ in French Soudan.

[Table I]

To evaluate the magnitude of these results, we can estimate the total average annual profit extracted by the colonizer between 1900 and 1945 as about 38 million 1914 francs. The total GDP of French West and Equatorial Africa in 1925 was about 1965 million 1914 francs (elaborations from Cogneau, Dupraz, and Mesplé-Somps 2018). This implies an average annual "extraction" of almost 2\% of GDP. Considering that the average per capita GDP growth was about $1 \%$ per year during the same period, the extent of extraction was quite significant.

The magnitude of these results suggests that it is important to fully consider the role of monopsonistic trade when evaluating the costs and benefits of colonization. Huillery (2014) finds that the average annual cost of colonization of West Africa (1844-1945), including military expenses, administration, and subsidies, was about 15 million 1914 francs per year for metropolitan France. The average annual profit from trade from West Africa between 1900 and 
1945 was about 27 million 1914 francs, showing that the profits from price gaps were such to largely pay for the cost of colonization.

Including the profit from monopsonistic trade also provides us with a more complete picture of transfers between the metropole and the colonies. Between 1907 and 1945, France's expenses for subsidies and administration amounted to only $0.47 \%$ of French West Africa revenue. On the other hand, companies' profit from colonial trade was equivalent to about one third of revenue of West and Equatorial Africa combined (115 million 1914 francs in 1925, elaborations from Cogneau, Dupraz, and Mesplé-Somps 2018). Monopsonistic trade accounted thus for most of the resources transferred between the colonies and the metropole.

\section{IV.2 Trends over Time}

Given the significance of the above results, it is interesting to analyze more in detail the trend of price reduction over time. Figure I shows average level of colonial extraction across all commodities and colonies, between early 1900s and 1959.

\section{[Figure I]}

At the beginning of colonial rule, in 1900, extraction was low at about $20 \%$. In the following years, as colonial rule became more established and trade monopsonies got stronger, it appears there was a steep rise in extraction, reaching 40-50\% in the 1910s. Similar levels persisted between the late 1920s and the Great Depression, when the decline of world market prices reduced the gap between competitive and actual African producer prices to about $30 \%$. After this period, colonial extraction reverted back to its previous levels until the end of WW2. After the war, it became more difficult for the colonizers to justify the use of coercive institutions in front of the public opinion both in France and in the colonies. Forced labor, for example, was abolished in 1946 in the entire French Africa. Compulsory productions in Equatorial Africa persisted for a little longer, but were also abolished in 1956. This trend was reflected in a reduction of colonial extraction: in the post-war period price gaps declined to about $20 \%$. Despite this improvement, at the eve of independence prices to African producers were still lower than competitive prices. Even if the colonizers relied less on labor coercion during the post-WW2 period, trade monopsonies persisted and so did colonial extraction. 
Was this general trend common to all colonies? Figure II presents the average extraction measure over time in French Equatorial and West Africa.

\section{[Figure II]}

Equatorial colonies (Gabon, Congo, Ubangi-Shari, and since the mid-1920s, Chad and Cameron) followed the general trend very closely, with higher average extraction. From low levels in 1900 , extraction quickly rose to almost $60 \%$ by 1920 . The rapid increase in colonial extraction can be linked to the intensifying of the operations of concessionary companies in the French Congo at the beginning of the XX century (Coquery-Vidrovitch, 1972). In the 1920s to early 1930s, price gaps decreased, consistently with both the abolition of the concession system and the 1929 crisis which reduced the profit margin of the trading companies (Suret-Canale, 1971). Then, since the late 1930s, extraction increased again to more than $60 \%$ during WW2. The consolidation of cotton compulsory cultivation in Ubangi-Shari and Chad can partly explain this rise (Dampierre 1960). After WW2, as coercive institutions lost their prominence, colonial extraction gradually diminished, reaching $20 \%$ at the end of the colonial period. In West Africa, the general trend was followed, but variations over time in the level of extraction were less pronounced than in Equatorial colonies. Overall, the extraction rate in Western colonies peaked at about $50 \%$ in the 1910 s and then declined, reaching $20 \%$ at independence. The lower level of extraction in West Africa is consistent with historical accounts of the less prominent use of coercion in Western with respect to Equatorial colonies (Manning 1998; Suret-Canale 1971; Thompson and Adloff 1957).

Observing extraction across territories, it is clear that, even if the general trend is common, there are important differences in the level and timing of variations. Did similar differences exist also across commodities? Figure III shows the evolution of extraction on cocoa, cotton, palm kernels, and peanuts, pooling the different colonies together.

\section{[Figure III]}

Peanuts were the main exports, accounting for about one third of the value of all trade from French West and Equatorial colonies during the period of the analysis. Palm kernels accounted for about $15 \%$, while cotton and cocoa accounted for about $5 \%$, respectively. Despite some variation, cocoa, palm kernels, and peanuts followed the general trend. From low levels at the 
beginning of the period, price gaps rose to almost $40 \%$. Then, after the temporary reduction during the Great Depression, extraction rates decreased finally to $20 \%$ near independence. Cotton, instead, experienced high levels of extraction already at the beginning of the colonial period (almost 60\%), which decreased to $40 \%$ in the 1920 s and to $20 \%$ in the post-war period.

\section{Robustness Checks}

The results of section IV show that there existed a large gap between actual and competitive producer prices. Yet, to be able to interpret this as evidence of colonial extraction, we need to make sure that we have not mismeasured prices or underestimated trading costs. In addition, we need to be able to rule out alternative explanations for these price differentials.

\section{V.1 Discussing Alternative Explanations for Price Gaps}

\section{Measurement Errors in Prices}

Commodity prices might be measured with errors. First, prices are computed as unit values (total value divided by total quantity) and can be prone to errors especially in the case of lowquantity observations. To check the robustness of the results against this type of inaccuracy, I tested whether extraction is positive $(e>0)$ when we exclude price data coming from observations with total quantity of 1000 tons or less. Doing so, the sample is reduced to 312 observations, but $e$ is still positive and statistically significant (average $=0.29$, st. err. $=0.01$ ).

Second, one might worry that, since exports were taxed on value, the trading companies underreported prices in order to reduce taxes. However, this cannot be the case since values were registered by customs offices on the basis of prices fixed by the colonial government. Since one the objectives of the colonial administrators was to increase the value of trade from the colonies, their incentives, if anything, must have been toward reporting higher and not lower prices at the African ports.

\section{Measurement Errors in Trade Costs}

How sensitive are the extraction estimates to different measures of trade costs? How large should trade costs be to cancel out the results? Following equation (2), larger inland trade costs $s$ (including processing costs, port charges, inland transport, and customs duties) increase the 
extraction estimate. It could be possible that real inland trade cost were actually smaller than my estimates, so that the computed extraction would be biased upwards. For example, monopsonistic trading companies could have paid very low wages to African porters or used coercion in the processing of goods, such as in the ginning of cotton. How sensitive is average extraction to reducing inland trade costs? By reducing inland costs by $50 \%$, extraction declines to 0.28 from 0.32 . Even if we considered an extreme case scenario with $s=0$, average extraction only slightly decreases to 0.25 . Varying inland trade costs cannot cancel out the results.

What about shipping and insurance costs $t$ ? The impact of an increase in shipping costs depends on the relative size of $t$ and $s$. If the estimates of $s$ were correct, we would need to increase $t$ by $400 \%$ to eliminate extraction. If instead the actual value of $s$ were zero, we would need to increase shipping and insurance costs by over $250 \%$. This exercise suggests that the extraction estimates are not very sensitive to the specific trade cost estimates. Extraction remains positive even allowing for a $100 \%$ reduction in inland trade costs and a simultaneous $250 \%$ increase in shipping and insurance costs.

\section{French Prices and World Prices}

One might wonder about the comparability between French and world market prices. Historians have in fact claimed that the French firms enjoyed prices lower than world prices for raw materials from the colonies (Amin 1973; Emmanuel 1973). Following this reasoning, it could be argued then that prices in France net of trading costs would not be a good counterfactual for African prices in the absence of colonial extraction. Nevertheless, if this is the case, the results of this paper are actually even stronger. If French prices were lower than world prices, then the gap between African and French prices is actually a lower bound of the gap between African and world prices.

To see how close French prices are to world prices, I estimated world prices in the following way. First, by using data from FAO (2016), I computed import unit-values in 1961 for each of the commodities, by averaging unit-values from all importing countries. Unit-values are directly comparable to my data on French port prices. In addition, by averaging across all countries we get a better estimate of world prices than if we just compared French prices to prices of other specific countries, such as the UK or the US. I then used the index of world price variation from Jacks (2013) to estimate world prices in every year from 1898 to 1959. As expected, prices at the French port were on average only about $80 \%$ of world prices. 
Figure IV reports the estimates of extraction over time, computed by using world instead that French prices.

[Figure IV]

As anticipated, the extraction rate is even larger, ranging from $40 \%$ to almost $80 \%$. With the exception of the initial period, the trend is also similar to the one in figure I, computing extraction rates from French prices. ${ }^{6}$

\section{Missing Data}

Given the nature of historical records, some data are missing. This would be a problem if somehow French prices were reported only when particularly high and African prices were reported only when particularly low. In this case, we would observe price gaps that are due to the non-random missing data. This seems, however, very unlikely. In general, data are missing because statistical publications disappeared or were too damaged to be consulted in the archives. For these reasons, it is plausible that the data will be missing due to random historical circumstances.

To check this, I tested whether specific colonies, commodities, or periods are particularly prone to missing data. For each colony and commodity, I considered all those observations for which we do not have information in years after the first year of recorded production as missing. To see whether data are missing at random, I regressed a dummy equal to one if data are missing and zero otherwise on 13 colony, 4 commodity, and 5 decade fixed effects (probit model). The idea here was to check whether missing data are correlated with observable and unobservable determinants of colonial extraction, proxied by the set of fixed effects. Despite the flexible functional form and the large set of independent variables, the adjusted pseudo- $\mathrm{R}^{2}$ of the regression is very low (14\%), which supports the hypothesis that missing data are not correlated with determinants of colonial extraction and thus not missing selectively.

\section{Market Frictions}

One might argue that we observe price gaps just because prices in Africa did not respond immediately to variations in world prices. These frictions can be due the slowness in the 
transmission of price information and inefficient arbitrage which characterized early twentieth century trade. In particular, if, because of these market rigidities, African prices would tend to remain low when world prices increased, we would observe positive gaps between African and French prices, which could not be attributed to colonial extraction.

To address this concern, consider that if $p_{A}=p-t-s$ at time 0 (no extraction) and African prices are "sticky", gaps at time 1 should be positive when the world price net of trading costs increases, but negative when the world price net of trading costs decreases. Thus, if we limit our analysis to years in which world prices net of trading costs decrease and we still find positive gaps, we can be confident that this is not due to market rigidities, but instead to colonial policies. In effect, when we reduce the sample to just those observations for which the competitive price at time 1 is lower than at time 0 , the average price gap is still positive (29\%) and statistically significant $(\mathrm{N}=261)$.

\section{Insurance of African Producers}

In the case of British colonies, trade monopsonies had the de jure aim to insure African producers against fluctuations of world market prices through the mechanism of marketing boards. Farmers had to sell their production to the government and were paid less than world prices when prices were high. The difference was collected by the marketing board and was used, in theory, to pay higher prices to farmers whenever world prices were low. Similar institutions were established in French Africa with the name of caisses de stabilisation. We could then think that the observed gap between prices in Africa and France might actually be an "insurance premium" which Africans had to pay in order to stabilize commodity prices.

This interpretation however is not likely. First, marketing boards did not fully reach their objective of insuring producers and soon became a way to transfer resources from farmers to urban sectors of the society in order to gain political support (Bates 1981). Moreover, marketing boards and caisses de stabilisation were established only late in the colonial period (since 1940 in British Africa and since 1954 in French Africa; Nabe 1999) and cannot explain price gaps that we observe from the 1900s to the 1940s. 
Quality Differences

Since prices to producers were fixed by the colonial government as a percentage of an average world price computed across different qualities (see Dampierre 1960, for cotton), we do not need to worry about observing different grades of the same crop in Africa with respect to France. Nevertheless, one might think that we observe gaps just because the quality of African commodities was lower than the average world quality. However, this is unlikely: African commodities are often of higher quality or they are the most common variety, so that African quality determines world quality. For example, the quality of African cotton, characterized by longer fibers, is higher than average (Basset 2005, cited in Moseley and Gray 2008); while the forastero cocoa cultivated in Africa, despite being of lower quality than the criollo and trinitario varieties, represents the greatest majority of world cocoa production (today, about 85\%).

Additional evidence comes from comparing extraction rates between commodities of different quality. If the gaps between African and world prices were due to quality differences (instead that to colonial extraction), we should expect larger gaps for commodities of lower quality. African cocoa was likely of lower quality, while African cotton was of higher quality, relatively to the world average. Yet, average extraction was $32 \%$ for cocoa and $39 \%$ for cotton (see table I). Finally, given their magnitude, quality differences cannot explain price gaps. Variations in quality can account for up to $15-35 \%$ of the difference in port prices within one commodity (Persson 2004). Since trading costs account for about one third the price difference between African and French port (see table II), even if we assumed the largest quality difference, we would still not be able to explain the residual $30 \%$ gap.

\section{[Table II]}

Investments in Africa

Even if it is now clear the described price gaps do exist, one might still be skeptical about interpreting them as evidence of extraction. In particular, one might argue that price differentials were used for colonial investments in public goods (transports, education, and health) that would benefit African populations. A closer look to colonial budgets show, however, that this could not be the case. First, such investments were mostly covered by local taxes. Second, colonial investments were small with respect to the profit from price 
differentials. Huillery (2014) provides relevant information on French West Africa. Colonial public investments included education, health, infrastructure, and support to productive sectors. Investments in health and education were extremely low: in an average year between 1907 and 1956 there were about 1,000 teachers and 1,400 doctors covering a population ranging from 12 to 25 million. Support to productive sectors was equally low while investments for infrastructure represented the majority of public investments. Before WW2, investments in infrastructure amounted to about 25 million 1914 francs per year, on average. The profits from price differentials from West Africa in the same period amounted at about 27 million per year. Even if the colonizers had used only price differentials to fund public investments, which is extremely unlikely, they would have still made a significant profit.

\section{Direct Evidence on Companies' Profitability}

The presence of large price gaps suggests that French trading companies in Africa were very profitable. Additional evidence from companies' dividend yields and profit margins confirm this hypothesis. In Equatorial Africa, the ten most successful companies in the French Congo accumulated 10 million francs in net profits in just seven years of activity from 1900 to 1906, equivalent to more than $7 \%$ of the total value of imports and exports (Suret-Canale 1971, p.3839). In West Africa, the dividend yield of the Compagnie Française de l'Afrique Occidentale, one of the major companies of the region, was 9\% in 1897-1899 (Société d'études coloniales de Belgique 1902, note 205-206), never dropped below 20\% between 1912 and 1915 (Anell and Nygren 1980, p. 81), and reached more than 26\% in 1916-1920 (Union Coloniale Française 1922, note 100). In 1945-1946, exporters of peanuts from Senegal enjoyed profits of 8.5\% net of all trade costs, and net profits were even higher on imports, ranging from $20 \%$ to over $40 \%$ depending on the produce (Suret-Canale 1971, p. 184-185).

As a comparison, the average interest rate on government bond in Europe in the same period was 3-5\% (Anell and Nygren 1980, p. 81). British firms' return on invested capital was 5.2\% between 1919 and 1963 (average of 10-years rolling return, Duignan and Gann 1975, p. 675-676) and the dividend yield of US companies in the S\&P500 was $3.7 \%$ in 1897-1899, 5.4\% in 1912-1915, and 6.8\% in 1916-1920 (Shiller 2015). Profit margins of French trading companies in Africa were comparable to those obtained by highly successful monopolistic colonial ventures, such as the Royal Niger Company, whose dividend yield was $7.5 \%$ in 1897 1898 (Pearson 1971, p. 83), or the Dutch East India Company, which for 150 years never 
yielded less than 11\% (Anell and Nygren 1980, p. 81). Moreover, they also were similar to those obtained in one of the most profitable industries in Africa: mining. South-African gold mines returned 9\% on invested capital between 1887 and 1965, while mines in the Belgian Congo returned 7.9\% between 1920 and 1939 (Duignan and Gann 1975, p. 675-676).

\section{V.2 Taking into Account Unobservable Costs: A Regression Approach}

The previous section ruled out several alternative explanations for price gaps. The observed differences between actual and competitive producer prices cannot be explained neither by measurement errors or missing data, nor by observable trading costs and relatively observable factors such as quality differences, market frictions, insurance of producers, or colonial investments. Yet, there might be other unobservable costs which could explain the difference between African and French prices. Since trade in Africa was risky, companies might have paid lower prices as a compensation against world price volatility or production shocks within Africa. Low producer prices could have been necessary to compensate for the cost of building trade posts and maintaining trade routes. There might have also been other unobservable transaction costs related to adulteration, spoilage during shipping, and bulking. Finally, productivity differences might also contribute to explain price gaps.

Unfortunately, all these costs are very difficult to measure. The evidence suggests however that they were not as important as we might think. As discussed at the beginning of section V.1 (Measurement Errors in Trade Costs), extraction remains positive even allowing for a $400 \%$ increase in shipping and insurance costs. If price gaps were due to unobservable costs, these should be very high compared to observable costs.

\section{Methodology}

Yet, to be able to construct precise estimates of extraction, we need to take these costs into account explicitly. To solve this problem, let us rewrite the definition of extraction $E$ from equation (1) as

$$
p_{A}=(1-E)(p-t-s)
$$


To estimate extraction $E$, I regress the actual producer price $p_{A}$ on the competitive producer price $p-t-s$

$$
p_{A c i t}=\alpha+\beta\left(p_{c t}-t_{c i t}-s_{c i t}\right)+u_{c i t}
$$

where $\beta=1-E, c$ identifies the commodity, $i$ the colony, $t$ the year, and $u_{c i t}$ is the error term. To run this regression, I estimated producer prices $p_{A}$ (which are not directly observable) as the difference between port prices $p_{P}$ and inland trade costs $s$. Under the null hypothesis of no colonial extraction ( $\mathrm{E}=0), \beta=1$; otherwise, with colonial extraction $(\mathrm{E}>0), \beta<1$. The average level of extraction can thus be measured as $1-\beta$. If we have a consistent estimator of $\beta$, then we have a measure of colonial extraction.

However, the estimation of $\beta$ could be inconsistent if trade costs $t$ and $s$ do not include all of the costs that the trading companies had to face to export commodities from Africa to France. To see why, suppose that the true regression is $p_{A c i t}=\beta\left(p_{c t}-t_{c i t}-s_{c i t}-c_{c i t}\right)+v_{c i t}$, where $c_{c i t}$ represents unobservable costs and $v_{c i t}$ is the new error term. Assume $\operatorname{Cov}(p, v)=\operatorname{Cov}(t, v)=\operatorname{Cov}(s, v)=0$. Standard results imply that, estimating $\beta$ by OLS from equation (4), $\operatorname{plim} \beta_{O L S}=\beta[1-(\operatorname{Cov}(p, c)-\operatorname{Cov}(t, c)-\operatorname{Cov}(s, c)) / \operatorname{Var}(p-t-s)]$. Thus, if $\operatorname{Cov}(p, c)-\operatorname{Cov}(t, c)-$ $\operatorname{Cov}(s, c)>0$, then the estimated coefficient would be biased against the null hypothesis of no extraction.

Even if it is reasonable to think that the correlation between unobservable costs $c$ and observable costs $t$ and $s$ is positive (implying a likely bias in favor of the null), the correlation between prices in France and omitted costs could also be positive, leaving the direction of the bias ambiguous. To reduce the impact of unobservable factors, I pursued two strategies. First, I controlled for unobservable costs by using fixed effects. Second, I used world prices as an instrument for competitive producer prices.

\section{Fixed effects}

I modeled unobservable costs as $c_{c i t}=k_{c i}+\theta_{t}$. The first component $k$ captures the differences in unobservable costs due to each commodity-colony; the second component $\theta$ captures the variation over time, common to all commodities-colonies. This is a mild assumption: I allowed unobservable costs to vary across commodity-colony and time, just assuming a common trend over time in all colonies and commodities. In the empirical specification, I implemented this idea by including commodity/colony and time fixed effects in equation (4). In this way, the relationship between competitive and actual prices in Africa is identified exclusively from the 
variation within each commodity/colony over time, after taking into account common timeshocks affecting all commodities and all colonies.

\section{Instrumental variables}

Another strategy to consistently estimate $\beta$ is to use instrumental variables. The IV approach is particularly useful to take into account those unobservable factors, such as business risk, which might change at a different rate over time across the different colonies and commodities. These type of unobservable factors are unlikely to be taken into account by year and colony/commodity fixed effects. Yet, if we find a variable which is correlated with the competitive price and uncorrelated with unobservable trade costs, then we can use it as an instrument to produce consistent estimates of the coefficient $\beta$.

The index of world prices by Jacks (2013) could serve as an instrument for competitive prices. World prices are obviously related to African competitive prices, but are not likely to be affected by unobservable costs between each French African colony and France. This is because French Africa only accounted for a minimal proportion of total world exports. In the late 1940s, for example, peanuts from Senegal, the main peanuts producer of French Africa, accounted for just $2 \%$ of world exports, while cocoa from Ivory Coast, the main cocoa producer, and palm kernels from Cameroon, the main palm kernels producer, accounted for only $4 \%$. Cotton from Chad, its main producer, reached $0.2 \%$ of total world exports only after independence. In the earlier years of the colonial period, these shares were even lower. In general, variations in world prices are likely to be exogenous since they are due to shocks in world supply and demand and are not affect by local factors.

\section{Results}

Tables III reports the results. To control for differences in inflation, both competitive and actual producer prices are deflated in constant francs by using inflation rates in France and in French Africa. ${ }^{7}$

\section{[Table III]}

In the first column, a simple regression is presented: the coefficient of the relationship is less than one and statistically significant. A one-franc increase in the competitive producer price generates only a 60-cents increase in the actual producer price. 
In column (2), I accounted for commodity-specific differences in inflation. Instead of deflating prices by inflation rates, I controlled for commodity-specific price deflators by interacting the inflation rates in France and French Africa with commodity dummies. In columns (3) and (4), I controlled for differences in productivity, proxied by the total quantity exported and indexes of soil suitability. These indexes are constructed by FAO (2016) by dividing each country in a set of $5 \times 5 \mathrm{~km}$ squares and estimating total potential production per hectare in each of these squares for each commodity. My measure of productivity is the average of these values for each colony and commodity, computed with GIS. In all specifications, the coefficient of interest is statistically lower than one, suggesting that the hypothesis of colonial extraction is robust to differences in inflation across commodities and differences in productivity across colonies/commodities.

In column (5), I used fixed effects to control for unobservable factors such as trade risk, uncertainty, and difficult-to-estimate transaction costs. I included both colony/commodity and year fixed effects. The coefficient of the competitive price is still lower than one. Even within the same colony and commodity, taken into account unobservable costs common to all observations in a given year, an increase in the competitive price is reflected in a less-thanproportional increase in the price that African producers received. In addition, it is interesting to notice that the coefficient with fixed effects is actually lower than the one from the simple OLS estimates. This suggest that unobservable costs are likely to bias the coefficient towards one and it is consistent with the fact that observable and unobservable costs tend to be correlated.

In column (6), I applied the other strategy to control for unobservable cost, by instrumenting the competitive price with the world price index. Colony/commodity and year fixed effects were also included. The first stage, reported in the bottom three rows of the table, shows that, as expected, world prices are positively correlated with competitive producer prices in Africa. Controlling by fixed effects, the relation is strong as shown by the large Fstatistics. In the second stage, the coefficient of the competitive prices is much smaller than one.

According to the estimates, actual producer prices were on average only half of what they should have been in a competitive market. In addition, notice that the coefficient from the last specification, which includes both instrumental variables and fixed effects, is not statistically different from the coefficient of the simple regression (column 1). This suggests that unobservable costs play at most only a minor role and gives us some more confidence that the estimates of extraction presented in section IV are correct. 


\section{Conclusions}

Extractive colonial institutions are considered one of the main causes of current African underdevelopment (Acemoglu, Johnson, and Robinson 2001; Nunn 2007). Yet, since colonial extraction is hard to quantify and its precise mechanisms are not well understood, a paucity of research has examined exactly how successful the colonizers were in extracting wealth from Africans.

In this paper, I sought to address this research gap by exploiting the peculiar structure of monopsonistic trade and coercive labor policies employed by the French colonizers. By using a newly collected dataset of export prices and trade costs, I constructed yearly estimates of extraction at the colony/commodity level for almost the entire colonial period, as proxied by the gap between actual prices to Africans and prices in a counterfactual competitive world. The findings of this research suggest that African prices were substantially lower than world market prices and that this difference cannot be explained by observables trading costs or other unobservable factors. According to the estimates, African producers would have enjoyed prices almost double if the colonizers had not employed extractive institutions.

Having quantified the extent of extraction through trade during the colonial period, the next step is to understand the details of the impact of colonial trade monopsonies and coercive institutions on current economic development. The level of extraction, in fact, varied greatly across colonies and commodities and this variation can help explaining the different paths of growth in African countries and regions. Moreover, the extractive character of these specific institutions persisted in the post-colonial era. Coercive labor institutions were abolished by independence, but trade monopsonies continued and post-independence governments kept practicing price policies, such as market boards and price control, which discriminated against agricultural producers. Given our clearer understanding of extraction during colonialism, future research aimed at examining how institutions established in colonial times still affect current agricultural trade policies and economic development is warranted. 


\title{
Footnotes
}

\begin{abstract}
${ }^{1}$ Extractive institutions can be defined as those arrangements "designed to extract incomes and wealth from one subset of society [masses, African populations] to benefit a different subset [elite, colonizers]" (Acemoglu and Robinson 2012). Specific examples from colonial times include forced labor and land alienation policies, monopolistic trade arrangements, and high levels of taxation combined with little provision of public goods.
\end{abstract}

${ }^{2}$ Previous works by economists often exploited spatial variation in some colonial policy or institution, observed at one point in time. Huillery (2009) studied the impact of colonial investments in education in French Africa. Gallego and Woodbery (2010) and Nunn (2010) analyzed the effect of colonial missionary activity on schooling and religious conversion. Michalopoulos and Papaioannou (2016) estimated the effect of arbitrary colonial borders on civil war. Berger (2009) studied the modern impact of colonial policies on public good provision in Nigeria. Notable exceptions are Cogneau and Moradi (2012)'s analysis of colonial policies across the border between French and British Togo, Huillery (2014)'s study of the costs of colonization for France, Frankema (2011)'s work on public finance in the British colonies, and Frankema and Van Waijenburg (2012)'s analysis of real wages in colonial Africa.

${ }^{3}$ Trade monopsonies as a mechanism of rent extraction were first emphasized by Bates (1981) in his analysis of marketing boards in British Africa.

${ }^{4}$ This result can be related to the finding by Yeats (1990), who shows that even in the postcolonial period the former French colonies paid, for import from France, prices which were 20-30\% higher than world market prices.

${ }^{5}$ The fact that smaller trading firms were able to operate show that the monopsonies which appeared in West Africa resulted more from a political plan to prevent entry in the market than from a market structure with high fixed costs.

${ }^{6}$ The reason why the trend in $1900-1920$ is different than in figure I is that, in some periods, French prices diverged from world prices. From 1900 to 1920 world prices were declining, while French prices were constant. For this reason, the extraction rate computed from world prices was decreasing, while the extraction rate computed from French prices was increasing.

${ }^{7}$ Data on the French inflation come from France-Inflation.com (2013). African inflation is estimated as explained in Online Appendix C 


\section{Acknowledgments}

Previous, substantially different, versions of this paper were circulated with titles Extractive Institutions and Gains from Trade: Evidence from Colonial Africa and Colonial Trade and Price Gaps in French Africa, and constituted the second chapter of my dissertation. I would like to thank my advisor Jean-Laurent Rosenthal for his excellent guidance. I also thank Nektarios Aslanidis, Jonathan Chapman, Jean Ensminger, Alfonso Herranz, Philip Hoffman, Nathan Nunn, Claudia Rei, Erik Snowberg, Matt Shum, and the participants to the Caltech HSS Proseminar, Caltech Social Science-History Lunch, All-UC Economic History Workshop at UC Berkeley, UCLA Economic History Proseminar, European Economic Association Conference in Toulouse, African Economic History Workshop at LSE, American Economic Association Meeting in Boston, Economic History Association Conference in Nashville, Workshop on Global History at the University of Warwick, EEHR Fast Track Meeting, seminars at Bocconi University, Australian National University, University of Waterloo, University Carlos III, and University of Barcelona, the Editor of this journal, and anonymous referees for very helpful comments and suggestions. 


\section{References}

Acemoglu, D. and Robinson, J. (2012). Why Nations Fail the Origins of Power, Prosperity, and Poverty. New York: Crown Publishing Group.

Acemoglu, D., Johnson, S., and Robinson, J. (2001). The colonial origins of comparative development: an empirical investigation. American Economic Review 91(5), pp. 1369-1401.

Acemoglu, D., Johnson, S., and Robinson, J. (2002). Reversal of fortune: Geography and institutions in the making of the modern world income distribution. Quarterly Journal of Economics 117(4), pp. 1232-1294.

Amin, S. (1973). L’Echange Inégal et la Loi de la Valeur. Paris: Editions Anthropos.

Anell, L. and Nygren B. (1980). The Developing Countries and the World Economic Order. London: Bloomsbury Academic.

Austin, G. (2008). The "reversal of fortune" thesis and the compression of history: Perspectives from African and comparative economic history. Journal of International Development 20 (8), pp. 996-1027.

BASSET, J. (2005). Price formation and power relations in cotton value chains of Mali, Burkina Faso and Cote d'Ivoire. Report prepared for Oxfam America, Boston.

BATES, R. (1981), Markets and States in Tropical Africa: The Political Basis of Agricultural Policies. Los Angeles: University of California Press.

BERGER, D. (2009). Taxes, institutions, and local government: evidence from a natural experiment in colonial Nigeria. New York University Working Paper.

Cogneau, D. and Moradi, A. (2014). Borders that divide: Education and religion in Ghana and Togo since colonial times, Journal of Economic History 74(3), pp. 694-729. 
Cogneau D., Dupraz Y., And Mesple-Somps, S. (2018). Fiscal Capacity and dualism in colonial states: The French empire 1830-1962. PSE Working Papers n²018-27.

Coquery-Vidrovitch, C. (1969). French Colonization in Africa to 1920: Administration and economic development. In Duignan, P. and GaHAN, L. H. (eds.), Colonialism in Africa, 1870-1970. Cambridge: Cambridge University Press, pp. 165-198.

Coquery-Vidrovitch, C. (1972). Le Congo au Temps des Grandes Compagnies Concessionnaires, 1898-1930. Berlin: Mouton De Gruyter.

DE DAMPIERRE., E. (1960) Coton noir, café blanc. Deux cultures du Haut-Oubangui à la veille de la loi-cadre. Cahiers d'études africaines 1(2), pp. 128-147.

Duignan, P. and Gann, L. H. (1975). Colonialism in Africa, 1870-1960. Boston: Cambridge University Press.

Emmanuel, A. (1969). L`Echange Inégal. Essai sur les Antagonismes dans les Rapports Economiques Internationaux. Paris: Editions Francois Maspero.

ENGLEBERT, P. (2000). Pre-colonial institutions, post-colonial states, and economic development in tropical Africa. Political Research Quarterly 53(1), pp. 7-36.

FAO (2016). Faostat Trade Database. Available at: http://faostat.fao.org.

FRANCE-INFLATION.COM (2013). Available at: http://france-inflation.com.

FRANKEMA, E. (2011). Colonial taxation and government spending in British Africa, 1880-1940: Maximizing revenue or minimizing effort? Explorations in Economic History 48(1), pp. 136-149.

Frankema, E. and VAn WaijEnBURG, M. (2012). Structural impediments to African growth? New evidence from real wages in British Africa, 1880-1965. Journal of Economic History 72(4), pp. 895-926. 
GALLEGO, F. and WoOdBerRY, R. (2010). Christian missionaries and education in former colonies: How competition mattered. Journal of African Economies 19(3), pp.294-329.

Herbst, J. (2000) States and Power in Africa: Comparative Lessons in Authority and Control. Princeton: Princeton University Press.

Hopkins, A. (1973). An Economic History of West Africa. New York: Columbia University Press.

HuILLERY, E. (2009). History matters: The long-term impact of colonial public investments in French West Africa. American Economic Journal - Applied Economics 1(2), pp. 176-215.

HUILLERY, E (2014). The black man's burden: The cost of colonization of French West Africa. Journal of Economic History 74(1), pp. 1-38.

JACKS, D. (2013). From boom to bust: a typology of real commodity prices in the long run. NBER Working Paper No. 18874.

Manning, P. (1982). Slavery, Colonialism, and Economic Growth in Dahomey, 1640-1980. Cambridge: Cambridge University Press.

Manning, P. (1998). Francophone Sub-Saharan Africa 1880-1995. Cambridge: Cambridge University Press.

Michalopoulos, S. and PAPAiOAnnou, E. (2016). The long-run effects of the scramble for Africa. American Economic Review, 106(7), pp. 1802-1848.

Lindert, P., Williamson J., and Milanovic, B. (2011). Pre-industrial inequality. Economic Journal 121(551), pp. 255-272.

Moseley, W. and Gray, L. C. (2008). Hanging by a Thread: Cotton, Globalization, and Poverty in Africa. Athens: Ohio University Press. 
NABE, B. (1999). Les instruments de régulation des prix des produits d'exportation et de la production agricole au Togo (1948-1964). CAMES B (1), pp.150-162.

NunN, N. (2007). Historical legacies: A model linking Africa's past to its current underdevelopment. Journal of Development Economics 83, pp. 157-175.

NunN, N. (2010). Religious conversion in colonial Africa. American Economic Review Papers and Proceedings 100(2), pp. 147-152.

PEARSON, S. R. (1971). The economic imperialism of the Royal Niger Company. Food Research Institute Studies 10(1), pp. 69-88.

PeEmans, J-P. (1975). Capital accumulation in the Congo under colonialism: The role of the state. In Duignan, P. and Ganan, L. H. (eds.), Colonialism in Africa, 1870-1970, vol. 4 Cambridge: Cambridge University Press, pp. 165-213.

PERSSON. K. G. (2004). Mind the gap! Transport costs and price convergence in the nineteenth century Atlantic economy. Journal of Economic History 8(2), pp. 125-147.

RoBerts, A. (1976). A History of Zambia. Portsmouth: Heineman.

Rodney, W. (1972). How Europe Underdeveloped Africa. London: Bogle-L'Ouverture Publications.

SHILLER R. (2015). Irrational Exuberance. Princeton: Princeton University Press.

SOCIETE D'ETUDES COLONIALES DE BELGIQUE (1902). Les sociétés coloniales françaises (et autres) à la Cote Occidentale d'Afrique. In Recueil des sociétés coloniales et maritimes. Bruxelles: Banque coloniale de Belgique.

Suret-Canale, J. (1971). French Colonialism in Tropical Africa, 1900-1945. New York: Pica Press. 
ThomAs, B. E. (1957). Railways and ports in French West Africa. Economic Geography, 33(1):115.

Thompson, V. and Adloff, R. (1957). French West Africa. Palo Alto: Stanford University Press.

Union Coloniale Francaise (1922). Annuaire des Entreprises Coloniales. Afrique Occidentale. Paris.

YeATS, J. (1990). Do African countries pay more for imports? Yes. The World Bank Economic Review 4(1), pp. 1-20.

YounG, C. (1994). The African Colonial State in Comparative Perspective. Yale University Press. 


\section{Figures and Tables ${ }^{1}$}

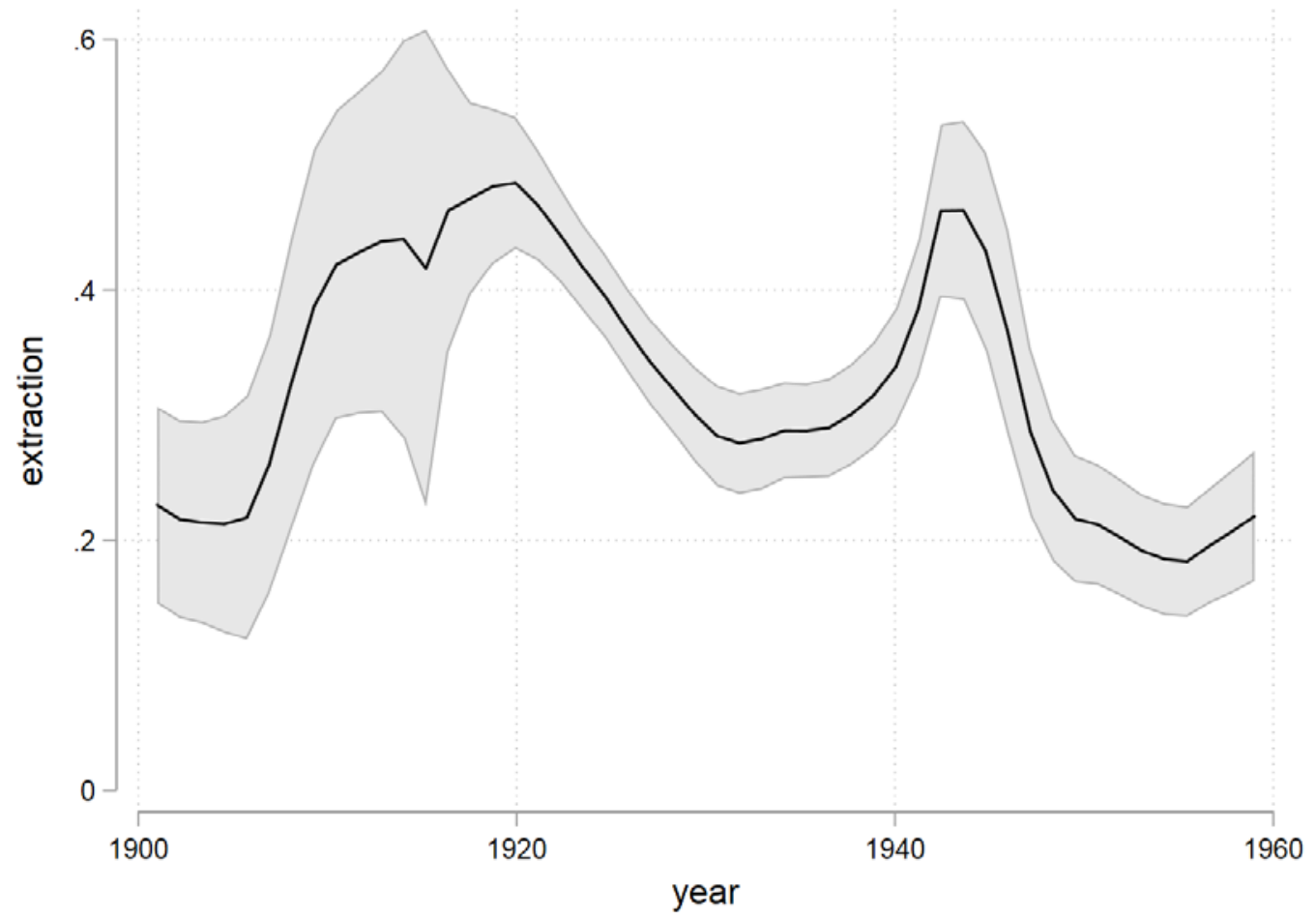

\section{Figure I}

\section{Colonial Extraction over Time (French prices)}

The figure shows the trend (local mean smoothing) of colonial extraction, defined as one minus the ratio between actual and competitive price at the producer level (see equation 2). All colonies and commodities are pooled together. The shaded area represents a 95\% confidence interval around the extraction estimates. See Online Appendix C for information on sources of price and trade costs data used in the construction of the extraction measure.

${ }^{1}$ Figures are produced by using the plotplain Stata code, developed by Bischof (2016), "New Figure Schemes for Stata: plotplain \& plotting". 


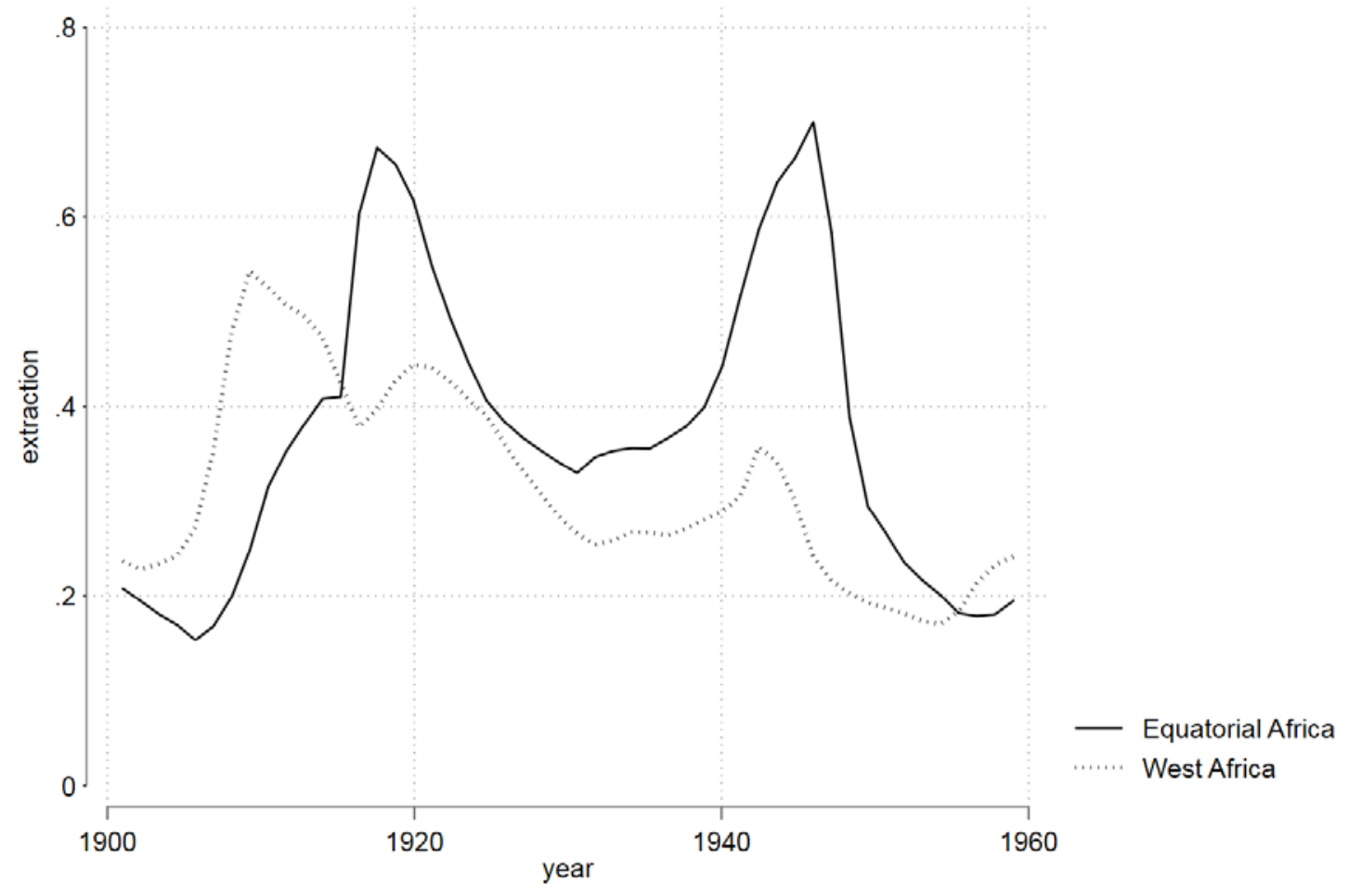

Figure II

Colonial Extraction over Time, in West and Equatorial Africa (French prices)

The figure shows the trend (local mean smoothing) of colonial extraction, defined as one minus the ratio between actual and competitive price at the producer level (see equation 2), in Equatorial and West French colonies. See Online Appendix C for information on sources of prices and trade costs data used in the construction of the extraction measure. 


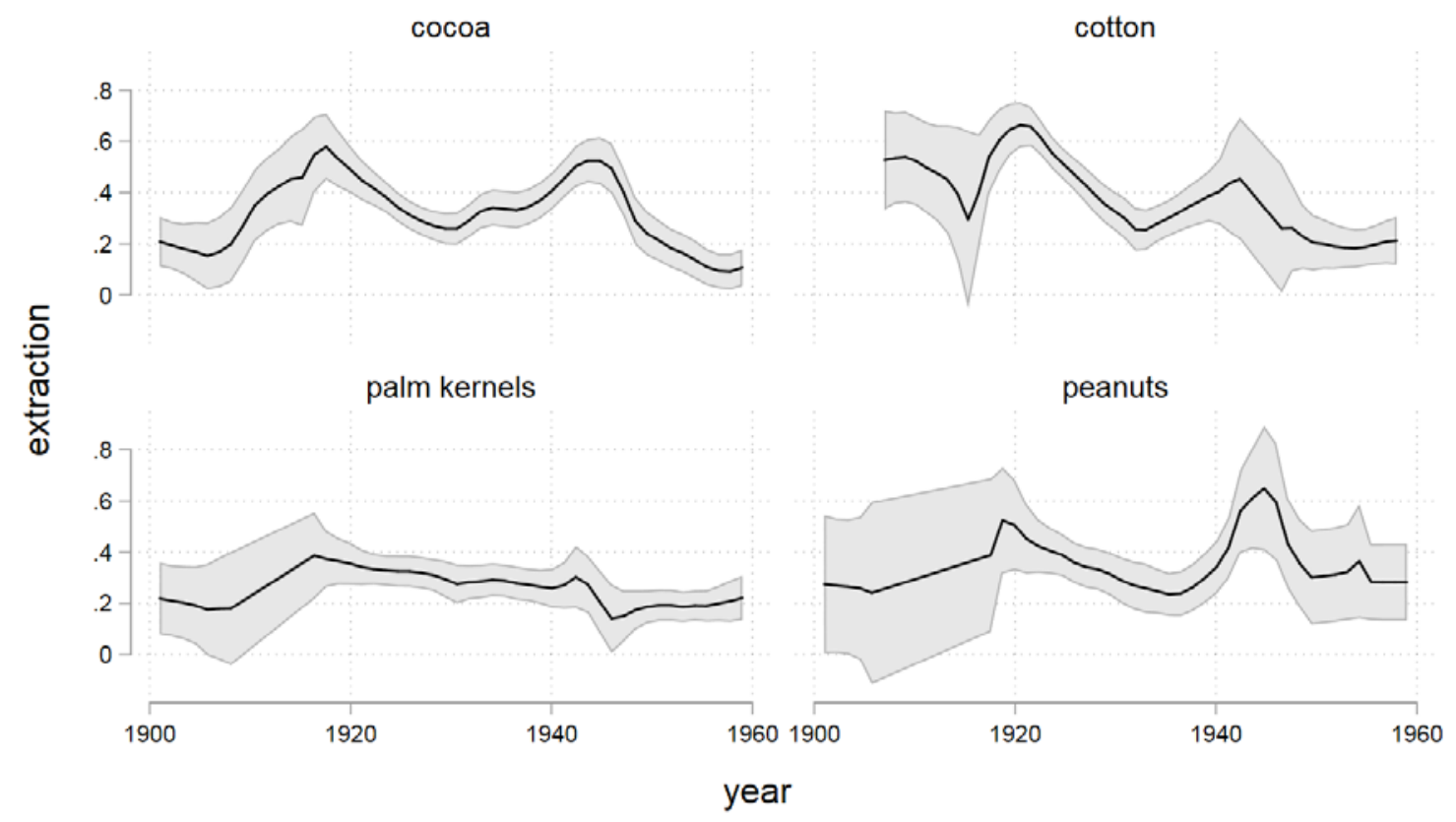

Figure III

Colonial Extraction over Time, by Commodity (French Prices)

The figure shows the trend (local mean smoothing) of colonial extraction, defined as one minus the ratio between actual and competitive price at the producer level (see equation 2). Graphs are presented separately by commodity. The shaded area represents a $95 \%$ confidence interval around the extraction estimates. See Online Appendix $\mathrm{C}$ for information on sources of prices and trade costs data used in the construction of the extraction measure. 


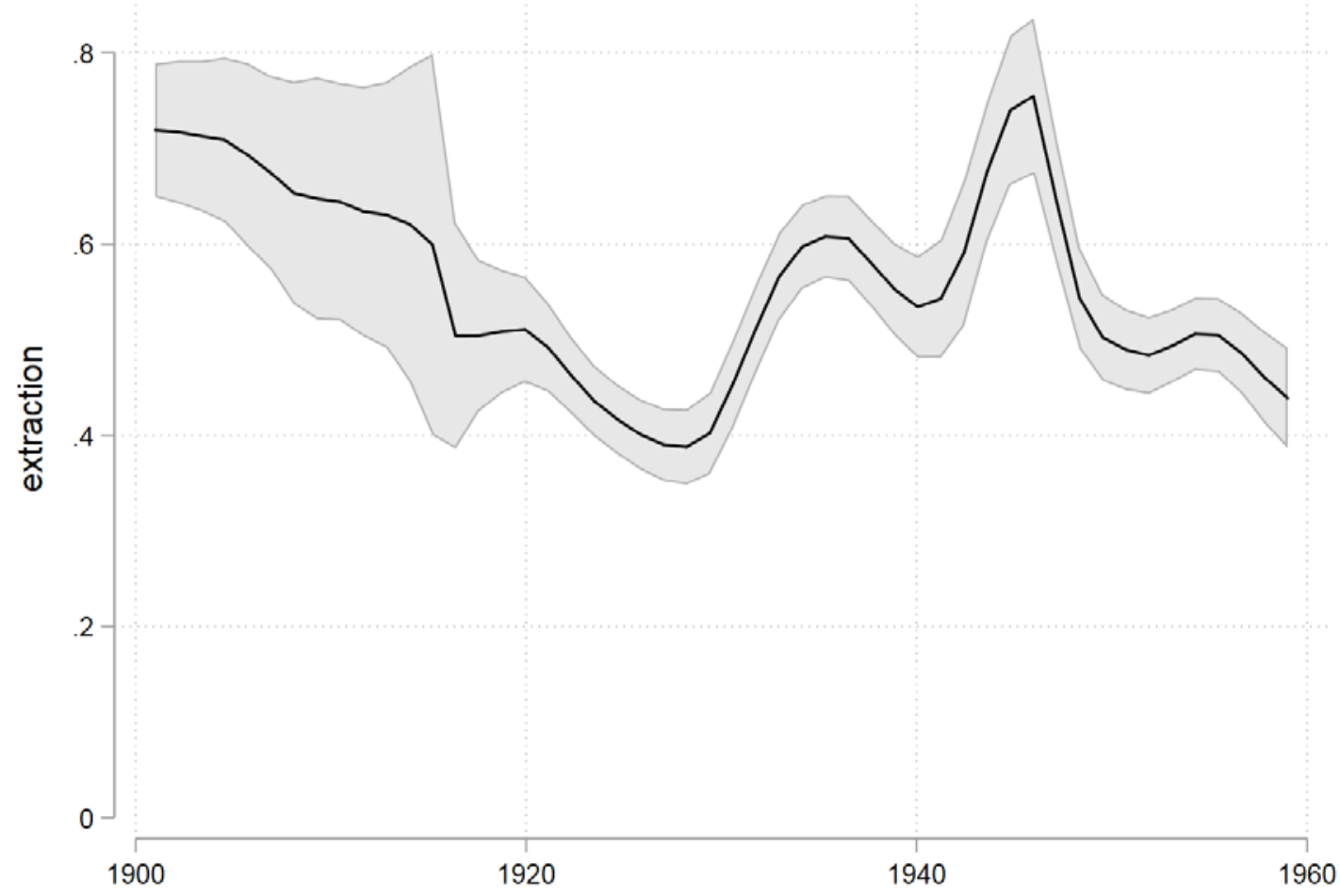

Figure IV

\section{Colonial Extraction over Time (World Prices)}

The figure shows the trend (local mean smoothing) of colonial extraction, defined as one minus the ratio between actual and competitive price at the producer level (see equation 2). Competitive prices are computed from world prices. All colonies and commodities are pooled together. The shaded area represents a 95\% confidence interval around the extraction estimates. See Online Appendix C for information on sources of prices and trade costs data used in the construction of the extraction measure. 
Table I

Measuring Colonial Extraction: Overall, By Period, By Commodity, and By Colony

French port

price

Overall
By period:

\section{By commodity:}

$\begin{array}{rccc}\text { pre-WW1 } & 1.18 & 0.76 & 0.93 \\ 1914-1929 & 5.06 & 3.98 & 3.83 \\ 1930 \mathrm{~s} & 2.57 & 1.81 & 1.80 \\ \text { WW2 } & 6.19 & 3.15 & 4.68 \\ \text { post-WW2 } & 166.10 & 121.46 & 119.72\end{array}$

competitive

producer price

$\begin{array}{rccc}\text { cocoa } & 52.98 & 113.14 & 46.41 \\ \text { cotton } & 75.21 & 127.17 & 44.25 \\ \text { palm kernels } & 20.31 & 31.10 & 15.81 \\ \text { peanuts } & 17.84 & 37.07 & 11.67\end{array}$

By colony:

\begin{tabular}{rcccccccccc} 
Cameroon & 28.37 & 86.48 & 22.78 & 74.06 & 18.78 & 66.09 & 0.96 & $\mathbf{0 . 3 4}$ & 0.21 & 57 \\
Chad & 171.22 & 150.51 & 68.73 & 66.77 & 45.16 & 45.98 & 0.97 & $\mathbf{0 . 3 9}$ & 0.21 & 6 \\
Congo & 58.55 & 89.74 & 45.49 & 77.17 & 39.16 & 72.30 & 0.97 & $\mathbf{0 . 3 4}$ & 0.23 & 26 \\
Dahomey & 42.63 & 90.16 & 30.12 & 59.29 & 24.99 & 50.22 & 0.99 & $\mathbf{0 . 2 8}$ & 0.19 & 60 \\
Gabon & 55.73 & 117.15 & 47.08 & 103.41 & 37.87 & 87.46 & 0.99 & $\mathbf{0 . 4 1}$ & 0.24 & 40 \\
Guinea & 15.17 & 36.04 & 11.94 & 30.36 & 8.89 & 22.60 & 1.00 & $\mathbf{0 . 2 9}$ & 0.17 & 44 \\
Haute-Volta & 200.87 & 121.04 & 139.03 & 78.21 & 98.46 & 56.14 & 0.95 & $\mathbf{0 . 3 0}$ & 0.16 & 4 \\
Ivory Coast & 51.83 & 96.35 & 39.75 & 73.15 & 31.69 & 61.59 & 0.98 & $\mathbf{0 . 2 8}$ & 0.16 & 71 \\
Niger & 91.73 & 14.02 & 40.56 & 11.59 & 22.90 & 3.72 & 1.00 & $\mathbf{0 . 4 0}$ & 0.18 & 3 \\
Senegal & 15.06 & 43.03 & 12.77 & 37.24 & 9.71 & 30.35 & 1.00 & $\mathbf{0 . 3 1}$ & 0.19 & 56 \\
Soudan & 6.90 & 4.96 & 4.23 & 3.36 & 1.45 & 1.84 & 0.78 & $\mathbf{0 . 7 4}$ & 0.23 & 9 \\
Togo & 9.61 & 33.66 & 7.21 & 23.56 & 4.92 & 15.55 & 0.99 & $\mathbf{0 . 2 9}$ & 0.18 & 61 \\
Ubangi-Shari & 178.19 & 147.91 & 98.44 & 75.64 & 80.71 & 62.42 & 0.98 & $\mathbf{0 . 1 9}$ & 0.21 & 11 \\
\hline
\end{tabular}

Correlations between French port price and actual producer prices are reported. The column of labeled "extraction" report mean estimates of "e", as defined in equation (2) and equivalent to "E" of equation (1) (i.e. extraction as a percentage of competitive counterfactual price). See Online Appendix C for information on sources of prices

actual

producer price

correlation extraction $\mathbf{N}$

st. dev. mean st. dev.

0.95

$\begin{array}{cc}0.66 & 0.63 \\ 2.97 & 2.21 \\ 1.32 & 1.27 \\ 2.63 & 2.23 \\ 93.27 & 97.02\end{array}$

0.50
1.83
0.90
1.51
82.12

0.84

0.78

0.88

0.62

0.90

$0.29 \quad 0.17$

$\begin{array}{lll}\mathbf{0 . 3 9} & 0.22 & 178\end{array}$

$\mathbf{0 . 2 8} \quad 0.16 \quad 122$

$\begin{array}{lll}\mathbf{0 . 5 0} & 0.22 & 23\end{array}$

99.89

38.80

86.96

0.99

$\begin{array}{lll}0.32 & 0.18 & 113\end{array}$

74.61

33.87

60.68

0.97

0.95

$\begin{array}{lll}\mathbf{0 . 3 9} & 0.22 & 96\end{array}$

24.95

12.59

20.26

$\begin{array}{lll}0.27 & 0.18 & 146\end{array}$

25.54

8.05

17.80

0.93

$\begin{array}{lll}\mathbf{0 . 3 3} & 0.23 & 93\end{array}$

By colony: and trade costs data used in the construction of the extraction measure. 
Table II

Prices in Africa, Trading Costs, and Prices in France

\begin{tabular}{|c|c|c|c|c|c|}
\hline variable & mean & st. dev. & $\min$ & $\max$ & $\begin{array}{c}\text { average } \% \\
\text { of price at } \\
\text { French } \\
\text { port }\end{array}$ \\
\hline producer price & 22.82 & 55.19 & 0.0032 & 346.60 & $50 \%$ \\
\hline total trading costs & 11.70 & 30.24 & 0.0892 & 205.99 & $28 \%$ \\
\hline processing & 4.55 & 19.18 & 0.0000 & 123.98 & $5 \%$ \\
\hline inland transport & 2.85 & 8.07 & 0.0038 & 64.14 & $10 \%$ \\
\hline port & 0.32 & 0.75 & 0.0013 & 3.58 & $1 \%$ \\
\hline export taxes & 1.97 & 6.41 & 0.0000 & 43.74 & $1 \%$ \\
\hline insurance & 0.40 & 0.88 & 0.0044 & 4.21 & $1 \%$ \\
\hline shipping & 1.60 & 2.89 & 0.0308 & 13.79 & $10 \%$ \\
\hline price at French port & 39.80 & 88.20 & 0.2200 & 421.12 & $100 \%$ \\
\hline
\end{tabular}

Values per kg in current French francs. Trading costs include both cost between the producer and the African port and costs from the African port to the French port. N=448. See Online Appendix C for information on sources of prices and trade costs. 
Table III

Relationship between Competitive and Actual Producer Price

(1)

(2)

(3)

(4)

(5)

(6)

OLS /Second Stage: dependent variable is the actual producer price

\begin{tabular}{|c|c|c|c|c|c|c|}
\hline competitive price, deflated & $\begin{array}{c}0.602^{* * *} \\
(0.088)\end{array}$ & & $\begin{array}{c}0.600^{* * *} \\
(0.090)\end{array}$ & $\begin{array}{c}0.599 * * * \\
(0.085)\end{array}$ & $\begin{array}{c}0.352^{* * * *} \\
(0.120)\end{array}$ & $\begin{array}{c}0.523^{* * *} \\
(0.154)\end{array}$ \\
\hline competitive price & & $\begin{array}{c}0.682^{* * *} \\
(0.099)\end{array}$ & & & & \\
\hline quantity (in 000s tons) & & & $\begin{array}{c}-0.000159 \\
(0.000251)\end{array}$ & & & \\
\hline cotton productivity & & & & $\begin{array}{c}-0.169 \\
(2.230)\end{array}$ & & \\
\hline cocoa productivity & & & & $\begin{array}{c}0.203 \\
(0.400)\end{array}$ & & \\
\hline palm kernels productivity & & & & $\begin{array}{l}-0.023 \\
(0.237)\end{array}$ & & \\
\hline peanuts productivity & & & & $\begin{array}{l}-0.010 \\
(0.29)\end{array}$ & & \\
\hline constant & $\begin{array}{c}0.222^{* * *} \\
(0.046)\end{array}$ & $\begin{array}{c}-1.987 * * \\
(0.768)\end{array}$ & $\begin{array}{c}0.226^{* * *} \\
0.0487\end{array}$ & $\begin{array}{c}0.170 \\
(0.340)\end{array}$ & & \\
\hline $\mathrm{N}$ & 448 & 448 & 448 & 448 & 448 & 448 \\
\hline $\mathrm{R}^{2}$ & 0.50 & 0.98 & 0.50 & 0.51 & 0.83 & 0.821 \\
\hline
\end{tabular}

Fixed Effects

Commodity yes

French inflation*commodity yes

African inflation*commodity yes

commodity*colony

year

$\begin{array}{ll}\text { yes } & \text { yes } \\ \text { yes } & \text { yes }\end{array}$

First Stage: dependent variable is the competitive producer price

world price index

F-stat IV

***, **, and * indicate statistical significance at $1 \%, 5 \%$, and $10 \%$ level with standard error clustered at the colony/commodity level (number of clusters=40). In the fixed effect regressions of columns (5) and (6), constants are not reported. Sources: see Online Appendix C and section V2. 